\title{
Pre-Service and In-Service Teachers' Perceptions toward White Board System Prior to Actual Experience
}

\author{
Ju Park \\ School of Education, Indiana University Northwest \\ *Corresponding Author: park49@iun.edu
}

Copyright $@ 2014$ Horizon Research Publishing All rights reserved.

\begin{abstract}
Using sample of survey data by pre-service and in-service teachers attending at a regional campus, this study examined how undergraduate and graduate students, in education major, perceived interactive white boards (IWB), and described implications of how the system can be used effectively, based on student-centered pedagogy. Although the participants saw a great potential to facilitate learning interaction and to promote student engagement with the IWB, issues of product training and funding for purchase were mainly concerned. Additionally, this study suggested that the participants' current perceptions toward the use of IWB may shift to more or less positive, if granted the opportunity to operate IWB in their local schools, since perceptions are transitioned through real life experience
\end{abstract}

Keywords Interactivity, SMART Board, Learning Process

\section{Introduction}

Activities for teaching and learning with Interactive White Board (IWB) have been implemented in K-12 and higher education institutions for enhancing student learning [1]. Among instructional technology devices and applications, the use of IWB has also changed the nature of teaching, in terms of pedagogical aspect, which has somewhat innovated teaching methods [2]. Betcher's study indicates a number of factors making implementation of IWB dissimilar to other instructional technology and also states that teaching integrated with IWB may help students benefit from student-centered classroom learning process, approached by teachers' interactive pedagogy. This study also suggests that implementation of IWB in education may be an integral part of multiple educational tools for student learning, by providing access to rich learning resources. Although teaching and learning technology does not always produce positive outcomes [3], it is still emphasized that teachers need to learn and understand how educational technology may enable students to meet competency of information, media, and technology skills, suggested by the Partnership for $21^{\text {st }}$ Century Skills, while still demanding creativeness in contemporary learning $[4,5]$.

In contemporary learning, it is not enough for students to simply know facts, by themselves. Rather, they need to work collaboratively with classmates in innovative and creative ways [6]. As collaborative learning with classmates have been encouraged in contemporary learning, the studies indicate that (a) students, when collaboratively prepared, showed positive outcomes on standards-based exams and demonstrated importance of collaboration in preparation for similar kinds of the exams [7] and (b) the collaborative works demanded a change in teachers' teaching practice for transformative learning assisted by technology integration [8]. In Hughes' study, teachers had to choose and implement one of three levels of technology adoption for change in teaching practice. The three levels of technology adoption are categorized, as follows: Replacement of existing pedagogical resources; amplification of the existing practice; and transformation of instructional practice. Teachers, in technology adoption aspect, may be categorized as one of the five types of adopters: Innovators, early adopters, early majority, late majority, and laggards. Teachers in a certain category would move up, depending on proper professional development they can receive $[1,9,10]$. Even though many teachers may not be innovators or early adopters in transformation of instructional practice assisted by technology integration, they are still encouraged to change their teaching practice and pedagogy, because they eventually need to integrate educational technology with textbooks for enabling students to have the $21^{\text {st }}$ Century Skills in this digital age. Since it is encouraged for teachers to transform traditional pedagogical practice with technology integration, the implementation of IWB in classrooms would help examine and identify positive and negative outcomes among teachers and students, based on learner-centered learning environment, and the previous studies have shown both positive and negative outcomes, when they utilized IWB $[11,12,13]$.

Particularly, one study suggests that a certain perspective of technology users may be subject to change, depending on how technology is introduced and implemented, during the course sessions [14]. It implies that, if teachers have negative 
preoccupation toward interactive instructional tools prior to actual use, they might not effectively utilize such tools in their classrooms. Regarding importance of teachers' conception toward interactive instructional tools, this study was particularly interested in examining how different and/or similar Indiana teachers' perceptions toward interactive white board system were, prior to actual use at their working schools (in-service teachers) or field-practicing schools (pre-service teachers).

\subsection{Pedagogical Approach with Interactive Tools}

Regarding positive aspect of technology integration into teaching impacted by the technological, pedagogical, and content knowledge (TPACK), they need to implement transformative teaching practice in which their use of interactive tools may produce effective learning outcomes, in order for K-12 teachers to be competent in $21^{\text {st }}$ century's contemporary teaching by technology assistance $[15,16]$. However, effective implementation of interactive tools, in terms of transformative teaching practice, is not a trouble-free activity, since utilization of the tools may cause several barriers: (a) teachers, who are reluctant learners, may not fully support such utilization, because they need to sacrifice additional times/tasks to be familiar with the tools; (b) not all teachers can get instant training/help support from their schools; and (c) teachers would have a misunderstanding about potential benefits and receive the misguided information by school administrators [16]. For instance, in elementary education, elementary teachers cover multiple subjects such as reading, math, and science for young learners, and implementation of interactive tools for elementary students' proper learning process may be so complex that the teachers need to understand technical, pedagogical, and content knowledge in order for them to overcome potential barriers [15].

In light of potential barriers, previous research was needed to investigate how such barriers and possible complexity could be overcome, while utilizing interactive tools by teachers $[9,11]$. Particularly, among other interactive tools for teaching and learning, interactive white board (IWB) may produce meaningful learning and active learning engagement. Moreover, teachers' attitude toward interactive white board implementation could still be affected by their understanding with training resources in which teachers' getting trained would not be an easy task, before they are fully engaged in IWB.

\subsection{Interactive White Board Use}

In previous research, teachers' and students' use of IWB have identified positive merits and negative concerns, regarding inception, utilization, and assessment $[9,17]$. In a very recent survey by Technology Horizon in Education [13], it states that 82 percent of the 517 respondents (K-12 teachers, principals, librarians, IT specialists, and the related people) showed that they have used IWB at work and indicated that IWB is one of the core technology systems, which is integral part for teaching practice and student learning. In this survey, there were various ways the respondents were affected by technology use (differentiated instruction, tracking student progress, improved communication, increased productivity, and others). Engagement into teaching and learning was top-ranked, which implied that tools/applications boosting teaching and learning engagement are preferred by educators. Furthermore, based on the user evaluation on IWB, the suggestions and concerns are the following:

- Student response system (e.g. Clickers) associated with IWB was an effective secondary tool.

- Good quality of training materials was needed for users who were not technology savvy.

- Time for student training by teachers, before student engagement as a class activity, was needed, but limited.

- Time for lesson preparation with IWB was substantially extended in which teachers felt stressed.

- Hardware and software needed to be revised, focusing on classroom settings, in term of usability issue.

- Instant IT support was significantly needed for repair, replacement, and maintenance.

Additionally, in the survey by Technology Horizon in Education [13], insufficient funding was the top reason that schools/districts were not able to acquire relevant educational technology tools/applications, implying that there was digital divide among schools/districts, nation-wide. Based on findings of research on digital divide $[18,19]$, not all schools would have costly instructional technology systems, and some schools may have difficulty to possess appropriate technology tools/applications. Considering that Northwest Indiana region has underserved K-12 schools where Black-American/Hispanic-American students are majority of the student body, along with low socio-economic status (SES), pre-service and in-service teachers in this region may not have full access to educational technology, compared to the well-served K-12 schools. In light of this concern, the School of Education at the regional campus of Indiana University System, where this study took place, has focused on proactive preparation for pre-service teachers who could be underprivileged on appropriate educational technology at their future schools and for in-service teachers who have been underserved for full access to effective educational technology; the School of Education have continuously been supported by various entities: Instructional Media Service (campus-wide) and University Information Technology Service (system-wide), as well as institutional support derived from the conceptual framework. Thus, this study was concerned with how differently pre-service and in-service teachers may have positive or negative perceptions toward IWB integration, before they are actually introduced to IWB system in a computer classroom, since all of the students cannot have equal 
opportunity or full access to IWB system.

\section{Methodology}

\subsection{Survey}

Pre-service and in-service teachers, who are undergraduate or graduate students seeking degree program or non-degree program, at the regional campus of Indiana University System received learning resources of IWB (electronic materials: YouTube video and learning content in web site of SMART Interactive White Board). After they were exposed to these materials for the length of one and half hours (Figure 1), they participated in the electronic survey through SurveyMonkey. Before conducting the survey, the participants, who had experience with interactive white board, were excluded from this survey in order to distinguish between data of the non-experienced users and data of the experienced users. The survey questions were adopted from the study of Morais [17] in which findings from the interview and survey questions on IWB were discussed. In this survey, two separate categories were provided: The first being, teachers' perception, in regard to pedagogy with IWB implementation; secondly, teachers' concerns, in regard to usability issues with IWB implementation. Allocating all of the questions to the participants was made by SurveyMonkey's automatic logic structure. Additionally, the participants had to initiate the survey through Oncourse (Indiana University System's Learning Management System developed by Sakai Community).
For data analysis, response cross-tabbing and filtering were used, based on the response summary report. Additionally, response categorizing and color-coding were used for qualitative data analysis $[20,21]$ in which open-ended feedback given by the participants was collected. Furthermore, for statistical analysis, Mannes-Whitney tests were utilized [22].

\subsection{Demographic Data}

The participants were drawn from three sections of the course, Computer Use in Education. Pre-service teachers had to take this required course, before entering the formal teacher education program at this University, assuming that they do not have full knowledge of content methods, nor formal field experience at local K-12 schools. At the time they took this course, some of them officially decided on which subject field to pursue (either single or dual) and the other was undecided. In-service teachers took this course, as an elective, seeking professional development credential or additional licensure endorsements. Due to issues of the survey participation eligibility and voluntary participation compliance, based on the IRB approval, 38 participants formally participated in this conducted survey. Among 38 participants, there were 31 pre-service teachers, whereas 7 teachers were in-service teachers. According to the subject field selection (either declared or currently in service), the top-ranked subject field was Elementary Education $(n=16)$ and the second ranked was Special Education $(\mathrm{n}=8)$, whereas the least ranked subject fields were Social Studies and History chosen by one participant, respectively (Figure 2).

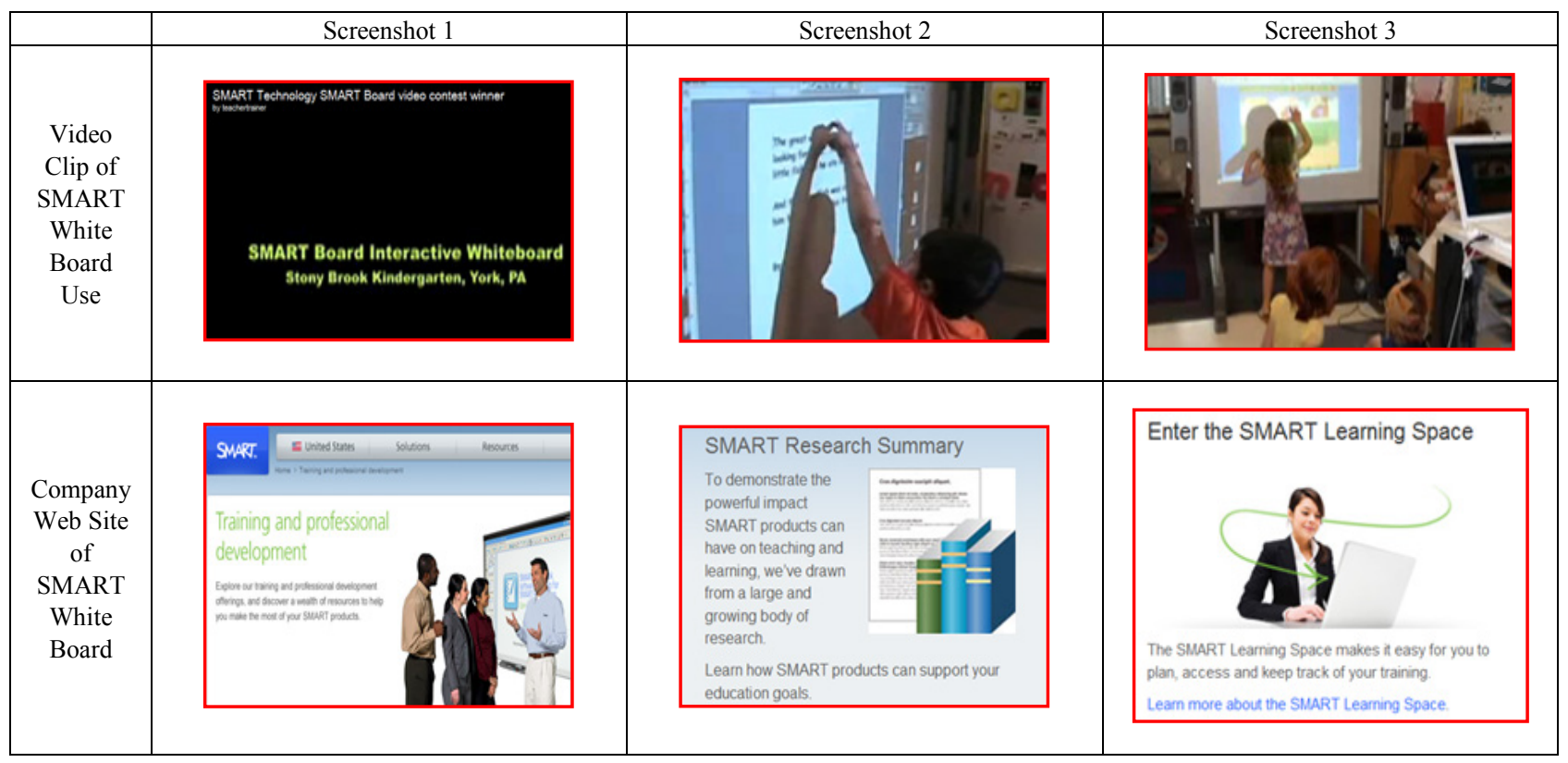

Figure 1. Materials Used for IWB Learning 


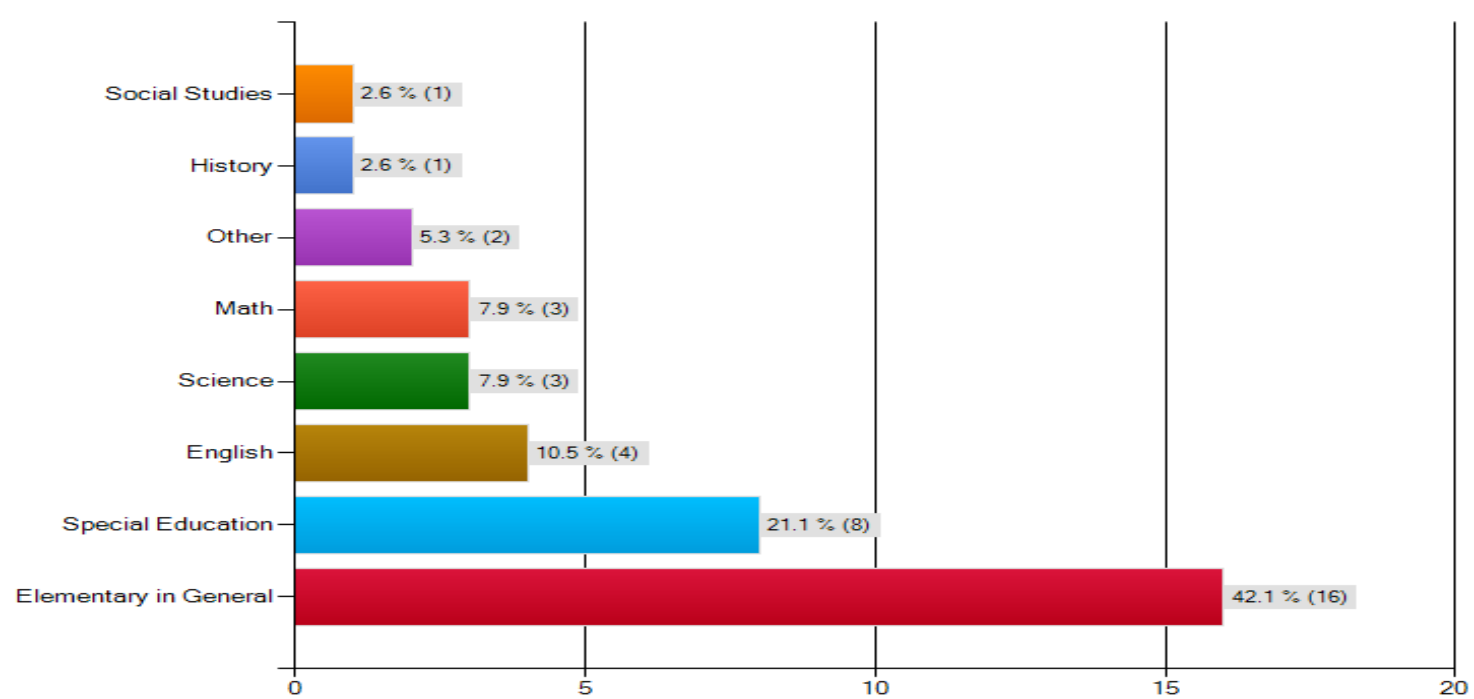

Figure 2. Subject Fields Selected by the Participants

Table 1. Perception toward IWB with Pedagogy Issues

\begin{tabular}{|c|c|c|c|c|c|}
\hline Questions & $\begin{array}{l}\text { Strongly } \\
\text { Agree }\end{array}$ & Agree & Disagree & $\begin{array}{l}\text { Strongly } \\
\text { Disagree }\end{array}$ & N/A \\
\hline Use of SMART Board may promote interactive teaching method & $\begin{array}{l}67.6 \% \\
(\mathrm{n}=25)\end{array}$ & $\begin{array}{l}27.0 \% \\
(\mathrm{n}=10)\end{array}$ & $\begin{array}{l}2.7 \% \\
(\mathrm{n}=1)\end{array}$ & $\begin{array}{l}2.7 \% \\
(\mathrm{n}=1)\end{array}$ & $\begin{array}{l}0.0 \% \\
(\mathrm{n}=0)\end{array}$ \\
\hline $\begin{array}{l}\text { SMART Board can be used by my students in terms of their active } \\
\text { engagement }\end{array}$ & $\begin{array}{l}45.9 \% \\
(\mathrm{n}=17)\end{array}$ & $\begin{array}{l}45.9 \% \\
(\mathrm{n}=17)\end{array}$ & $0.0 \%(\mathrm{n}=0)$ & $\begin{array}{l}2.7 \% \\
(n=1)\end{array}$ & $\begin{array}{l}5.4 \% \\
(n=2)\end{array}$ \\
\hline Use of SMART Board enables me to diversify my teaching strategies & $\begin{array}{l}45.9 \% \\
(n=17)\end{array}$ & $\begin{array}{l}45.9 \% \\
(\mathrm{n}=17)\end{array}$ & $0.0 \%(n=0)$ & $\begin{array}{l}2.7 \% \\
(\mathrm{n}=1)\end{array}$ & $\begin{array}{l}5.4 \% \\
(\mathrm{n}=2)\end{array}$ \\
\hline SMART Board can be used for group activity/group project & $\begin{array}{l}35.1 \% \\
(\mathrm{n}=13)\end{array}$ & $\begin{array}{l}59.5 \% \\
(\mathrm{n}=22)\end{array}$ & $5.4 \%(n=2)$ & $\begin{array}{l}0.0 \% \\
(\mathrm{n}=0)\end{array}$ & $\begin{array}{l}0.0 \% \\
(\mathrm{n}=0)\end{array}$ \\
\hline $\begin{array}{l}\text { Touch screen function is well designed for interactive instruction } \\
\text { method }\end{array}$ & $\begin{array}{l}42.9 \% \\
(\mathrm{n}=15)\end{array}$ & $\begin{array}{l}45.7 \% \\
(\mathrm{n}=16)\end{array}$ & $2.9 \%(n=1)$ & $\begin{array}{l}0.0 \% \\
(\mathrm{n}=0)\end{array}$ & $\begin{array}{l}8.6 \% \\
(\mathrm{n}=3)\end{array}$ \\
\hline
\end{tabular}

\section{Findings}

\subsection{Perceptions toward IWB with Pedagogy Issues}

In this category, $67.6 \%(n=25)$ of the participants strongly agreed that the use of SMART Board may promote interactive teaching method (Table 1). Regarding engagement, $45.9 \%(n=17)$ and $45.9 \%(n=17)$ of the participants agreed and strongly agreed, respectively, in statement, "SMART Board can be used by my students in terms of their active engagement". Interestingly, since the strong interaction between teacher and students may help teachers facilitate ways of active engagement [9], most of the participants showed that touchscreen feature of SMART Board may promote teachers' interactive teaching method ( $\mathrm{n}=15$ in strongly agree; $\mathrm{n}=16$ in agree), whereas the one participant did not see such standpoint.

Additionally, when the participants were asked which grade level would most benefit from IWB implementation, more than $50 \%$ of the participants selected all of the grade levels: Kindergarten $(n=19)$; college/university $(n=24)$; elementary school ( $\mathrm{n}=27)$; high school $(\mathrm{n}=27)$; and middle school $(\mathrm{n}=28)$. Since this particular inquiry allowed the participants to choose all that applies, multiple selections by each individual were made so that, evidently, the participants considered that IWB implementation may benefit $\mathrm{K}-12$ schools relatively more than college/university level $(75.9 \%$ in $\mathrm{K}-12 ; 66.7 \%$ in College/University; Figure 3). 


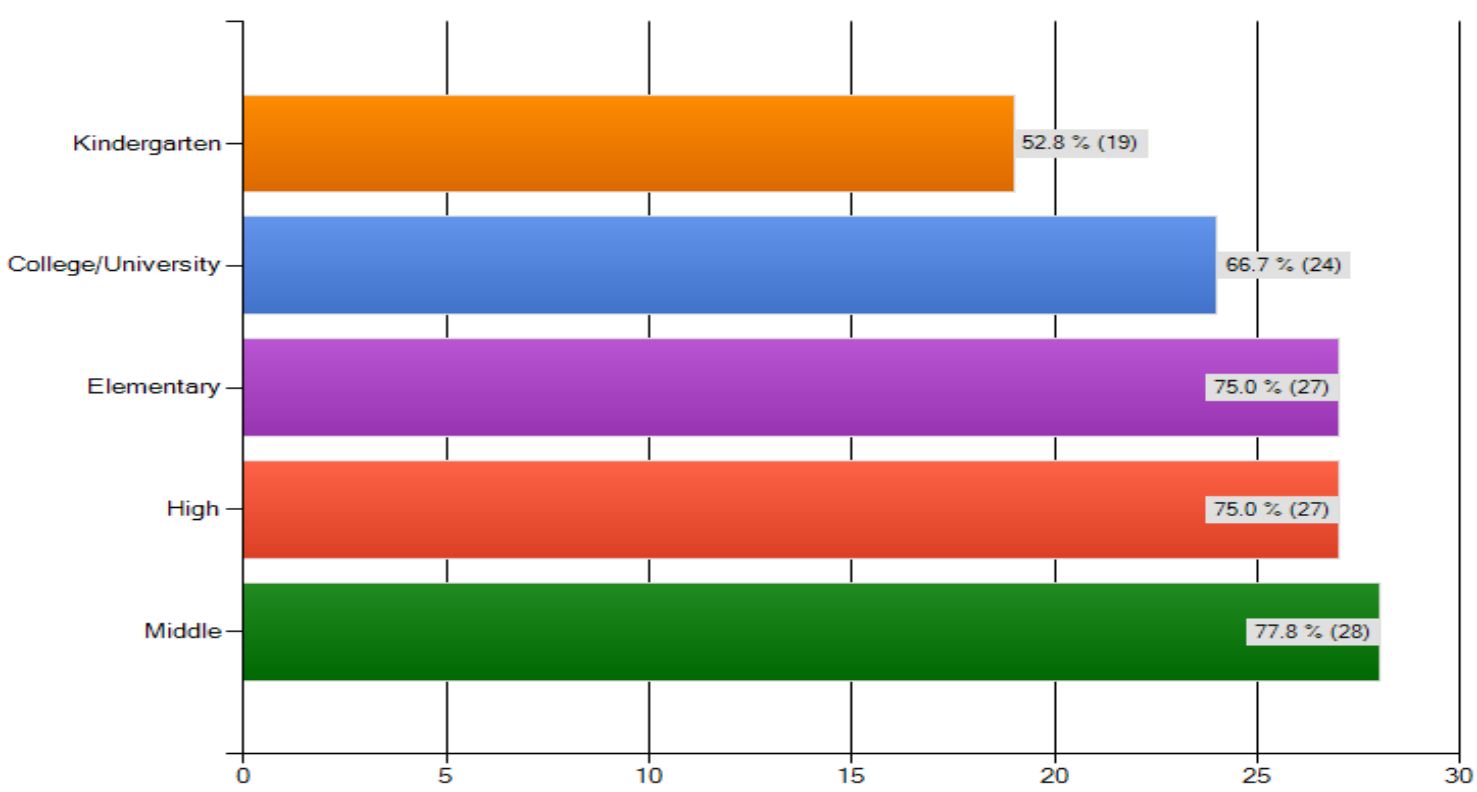

Figure 3. Grade Levels in which IWB Could Be Most Effectively Used

Table 2. Concerns of Non-Pedagogy Issues

\begin{tabular}{|c|c|c|c|c|c|}
\hline Questions & $\begin{array}{l}\text { Strongly } \\
\text { Agree }\end{array}$ & Agree & Disagree & $\begin{array}{l}\text { Strongly } \\
\text { Disagree }\end{array}$ & N/A \\
\hline $\begin{array}{l}\text { SMART Board is the well-designed product regarding } \\
\text { user-friendliness }\end{array}$ & $\begin{array}{l}51.4 \% \\
(\mathrm{n}=19)\end{array}$ & $\begin{array}{l}43.2 \% \\
(\mathrm{n}=16)\end{array}$ & $2.7 \%(n=1)$ & $0.0 \%(n=0)$ & $\begin{array}{l}2.7 \% \\
(\mathrm{n}=1)\end{array}$ \\
\hline $\begin{array}{l}\text { I believe that school teachers appreciate this product, if properly } \\
\text { provided with training support }\end{array}$ & $\begin{array}{l}51.4 \% \\
(n=19)\end{array}$ & $\begin{array}{l}48.6 \% \\
(n=18)\end{array}$ & $0.0 \%(\mathrm{n}=0)$ & $0.0 \%(n=0)$ & $\begin{array}{l}0.0 \% \\
(\mathrm{n}=0)\end{array}$ \\
\hline $\begin{array}{l}\text { If there is an demonstration/training video of SMART Board, it will } \\
\text { be helpful for beginning users }\end{array}$ & $\begin{array}{l}61.1 \% \\
(\mathrm{n}=22)\end{array}$ & $\begin{array}{l}38.9 \% \\
(\mathrm{n}=14)\end{array}$ & $0.0 \%(\mathrm{n}=0)$ & $0.0 \%(n=0)$ & $\begin{array}{l}0.0 \% \\
(\mathrm{n}=0)\end{array}$ \\
\hline $\begin{array}{l}\text { I believe that purchasing a new SMART Board is worthwhile to } \\
\text { invest }\end{array}$ & $\begin{array}{l}41.7 \% \\
(n=15)\end{array}$ & $\begin{array}{l}50.0 \% \\
(\mathrm{n}=18)\end{array}$ & $5.6 \%(\mathrm{n}=2)$ & $0.0 \%(\mathrm{n}=0)$ & $\begin{array}{l}2.8 \% \\
(\mathrm{n}=1)\end{array}$ \\
\hline
\end{tabular}

\subsection{Concerns of Non-Pedagogy Issues}

In this category, non-pedagogy issues such as usability and training support (Table 2) were reported, which may impact on teachers' attitude and pedagogical strategy [1]. 51.4\% $(\mathrm{n}=19)$ of the participants strongly agreed that SMART IWB is well designed to comply user-friendliness, whereas $2.7 \%(n=1)$ showed disagreement. Higher than $90 \%$ of the participants indicated that appropriate training support is strongly needed to help teachers implement IWB ( $\mathrm{n}=19$ in strongly agree; $\mathrm{n}=18$ in agree). Meanwhile, more than $90 \%$ of the participants agreed that tech training material (e.g. training video) may help the beginning users in IWB implementation. Peculiarly, although many K-12 teachers, principals, and superintendents are aware of funding issues to purchase appropriate instructional technology equipment and applications [13], most of the participants in this survey expressed positive views on instructional technology investment, in which purchasing a new SMART board is a worthwhile investment ( $\mathrm{n}=15$ in strongly agree; $\mathrm{n}=18$ in agree; $\mathrm{n}=2$ in disagree; $\mathrm{n}=1$ in non-applicable).

\subsection{Comparison between Pre-Service and In-Service Teachers}

For the statistical examination of the group comparison, Mannes-Whitney test was conducted, since in-service teachers group population was less than 20 [22].

Mannes-Whitney Test revealed statistically no significant differences between pre-service group and in-service group, as it showed that all of the null hypotheses over each question item were not rejected (Table 3; testing item 1 through 9 respectively corresponded to question item 4 through 12 in the survey). This implies that participants in pre-service group and in-service group have similar tendency over the questions asked regarding their perceptions toward IWB utilization. 
Table 3. Mannes-Whitney Test for Group Difference

\section{Hypothesis Test Summary}

\begin{tabular}{|c|c|c|c|c|c|c|c|c|c|}
\hline & Null Hypothesis & Test & Sig. & Decision & & & & & \\
\hline 1 & $\begin{array}{l}\text { The distribution of Your Choice is } \\
\text { the same across categories of Are } \\
\text { you currently an in-service } \\
\text { teacher?. }\end{array}$ & $\begin{array}{l}\text { Independent- } \\
\text { Samples } \\
\text { Mann- } \\
\text { Whitney U } \\
\text { Test }\end{array}$ & 1.000 & $\begin{array}{l}\text { Retain the } \\
\text { null } \\
\text { hypothesis. }\end{array}$ & & & & & \\
\hline 2 & $\begin{array}{l}\text { The distribution of Your Choice is } \\
\text { the same across categories of Are } \\
\text { you currently an in-service } \\
\text { teacher?. }\end{array}$ & $\begin{array}{l}\text { Independent- } \\
\text { Samples } \\
\text { Mann- } \\
\text { Whitney U } \\
\text { Test }\end{array}$ & .660 & $\begin{array}{l}\text { Retain the } \\
\text { null } \\
\text { hypothesis. }\end{array}$ & 6 & $\begin{array}{l}\text { The distribution of Your Choice is } \\
\text { the same across categories of Are } \\
\text { you currently an in-service } \\
\text { teacher?. }\end{array}$ & $\begin{array}{l}\text { Independent- } \\
\text { Samples } \\
\text { Mann- } \\
\text { Whitney U } \\
\text { Test }\end{array}$ & 1.000 & $\begin{array}{l}\text { Retain the } \\
\text { null } \\
\text { hypothesis. }\end{array}$ \\
\hline 3 & $\begin{array}{l}\text { The distribution of Your Choice is } \\
\text { the same across categories of Are } \\
\text { you currently an in-service } \\
\text { teacher?. }\end{array}$ & $\begin{array}{l}\text { Independent- } \\
\text { Samples } \\
\text { Mann- } \\
\text { Whitney U } \\
\text { Test }\end{array}$ & .528 & $\begin{array}{l}\text { Retain the } \\
\text { null } \\
\text { hypothesis. }\end{array}$ & 7 & $\begin{array}{l}\text { The distribution of Your Choice is } \\
\text { the same across categories of Are } \\
\text { you currently an in-service } \\
\text { teacher?. }\end{array}$ & $\begin{array}{l}\text { Independent- } \\
\text { Samples } \\
\text { Mann- } \\
\text { Whitney U } \\
\text { Test }\end{array}$ & 1.000 & $\begin{array}{l}\text { Retain the } \\
\text { null } \\
\text { hypothesis. }\end{array}$ \\
\hline 4 & $\begin{array}{l}\text { The distribution of Your Choice is } \\
\text { the same across categories of Are } \\
\text { you currently an in-service } \\
\text { teacher?. }\end{array}$ & $\begin{array}{l}\text { Independent- } \\
\text { Samples } \\
\text { Mann- } \\
\text { Whitney U } \\
\text { Test }\end{array}$ & .189 & $\begin{array}{l}\text { Retain the } \\
\text { null } \\
\text { hypothesis. }\end{array}$ & 8 & $\begin{array}{l}\text { The distribution of Your Choice is } \\
\text { the same across categories of Are } \\
\text { you currently an in-service } \\
\text { teacher?. }\end{array}$ & $\begin{array}{l}\text { Independent- } \\
\text { Samples } \\
\text { Mann- } \\
\text { Whitney U } \\
\text { Test }\end{array}$ & .655 & $\begin{array}{l}\text { Retain the } \\
\text { null } \\
\text { hypothesis. }\end{array}$ \\
\hline 5 & $\begin{array}{l}\text { The distribution of Your Choice is } \\
\text { the same across categories of Are } \\
\text { you currently an in-service } \\
\text { teacher?. }\end{array}$ & $\begin{array}{l}\text { Independent- } \\
\text { Samples } \\
\text { Mann- } \\
\text { Whitney U } \\
\text { Test }\end{array}$ & 1.000 & $\begin{array}{l}\text { Retain the } \\
\text { null } \\
\text { hypothesis. }\end{array}$ & 9 & $\begin{array}{l}\text { The distribution of Your Choice is } \\
\text { the same across categories of Are } \\
\text { you currently an in-service } \\
\text { teacher?. }\end{array}$ & $\begin{array}{l}\text { Independent- } \\
\text { Samples } \\
\text { Mann- } \\
\text { Whitney U } \\
\text { Test }\end{array}$ & .443 & $\begin{array}{l}\text { Retain the } \\
\text { null } \\
\text { hypothesis. }\end{array}$ \\
\hline
\end{tabular}

Asymptotic significances are displayed. The significance level is .05 .

Table 4. Categorized Data of the Participants' Perceptions toward IWB Implementation

\begin{tabular}{|c|c|}
\hline Categories & Sample Responses \\
\hline Support on IWB & It's wonderful idea (pre-service teacher). \\
\hline $\begin{array}{l}\text { Benefits of IWB in Teaching } \\
\text { Practice }\end{array}$ & $\begin{array}{l}\text { Think it's very effective because any tool that will engage a mind to function at a higher level and } \\
\text { think at a more in depth level is an effective tool (pre-service teacher). } \\
\text { I think that the smart board obviously could be beneficial (pre-service teacher). } \\
\text { The SMART board is a very creative and essential tool that needs to be in every classroom (in-service } \\
\text { teacher). } \\
\text { The smart board is a wonderful interactive tool. I truly believe every school should have them in } \\
\text { ev[e]ry classroom. The benefits far out way the cost (pre-service teacher). } \\
\text { I believe that the SMART Board is a wonderful interactive tool teachers should take full advantage of } \\
\text { (pre-service teacher). }\end{array}$ \\
\hline $\begin{array}{l}\text { Barriers in } \\
\text { Implementation }\end{array}$ & $\begin{array}{l}\text { I honestly even at } 25 \text { like a piece of chalk a blackboard and a projector and that is either free or very } \\
\text { reasonable. I would much rather spend my money on things that will benefit my children in other } \\
\text { ways (pre-service teacher). } \\
\text { Especially since schools are having a hard time financially, smart boards may not be a great idea until } \\
\text { they are more affordable. I think that perha[p]s the cost of this tool may be larger than its value } \\
\text { (in-service teacher). } \\
\text { Needs some kinks to have worked out on it (pre-service teacher). }\end{array}$ \\
\hline $\begin{array}{l}\text { Concerns about } \\
\text { Implementation }\end{array}$ & $\begin{array}{l}\text { SMART Boards can be useful in all levels but different subjects are limited by technology, such as } \\
\text { math, technology can't change how to teach math besides (pre-service teacher). } \\
\text { The truth is that there will always be another new form of technology (pre-service teacher). }\end{array}$ \\
\hline
\end{tabular}




\subsection{Qualitative Responses}

Overall, as displayed in Table 4, the participants (pre-service and in-service teachers) showed positive views on the use of SMART white board system. Their views specifically show that utilizing such white board systems may (a) allow teachers to effectively instruct, (b) enable students to be interactively engaged, and (c) make students creative in the learning process. However, they were also concerned with potential barriers, upon implementation. Explicitly, they kept in mind that (a) having the white board system is largely dependent on funding affordability in which many K-12 schools have struggled for funding acquisition [23], (b) the cost of such system purchase would be more than its value, itself, and (c) funds that can purchase such systems need to be spent for other things, since free and very reasonable similar products are available.

Briefly, the participants seemed to agree that the use of SMART white board system may generate positive outcomes of learning by teachers' effective implementation in technology-assisted pedagogy. Nonetheless, they seemed to be concerned about funding issues that may keep decision makers from appropriately acquiring such systems, depending on purchase cost and value of prospective results.

\section{Discussion}

The previous studies have indicated various results and recommended helpful suggestions on IWB integration into teaching practice and student learning, along with motivation concern [12]. Among the suggestions, Bitter and Legacy [1] note that instructional technology equipment/systems like IWB and its applications should be wisely evaluated and selected by decision makers (technology lead teachers, principals, superintendents, and IT specialists) in K-12 schools. It is important to make sure that the chosen products satisfy concerns of credibility, audience, user-friendliness, accessibility, and many others, because otherwise, cost for acquisition, time for processing, and labor for training could be wasted. Among various evaluation criteria, the degree of user-friendliness is typically evaluated by teachers through a product trial period, because there may be discrepancies between the vendor's information of products and what the users actually experience. However, since many schools and their districts have suffered from insufficient funding for instructional technology purchase [23], reliable evaluation factor of user-friendliness may not be completely fulfilled, because free demo and trial products do not normally come with full functionality. As a result, purchase determination may be affected by teachers' perception toward instructional technology products, that is, if they are allowed to learn about a particular product with marketing materials (print-based product brochure, electronic based product demo, and web site describing the product). In order to add further understanding to the educational use of IWB with different viewpoints by pre-service and in-service teachers, who do not have direct experience with the system, an inquiry of this study at the regional campus of Indiana University System was needed to examine the positive and negative perceptions toward IWB, although they learned about IWB with electronic resources only.

Findings in this study reconfirm prospective and positive benefits upon IWB utilization in K-12 environments, implying that indirect experience of teachers seems to find way of effective pedagogy integrated with IWB, based on interactive learning modules.

According to the recent report [24], it is necessary to plan wisely, operate effectively, and obtain successful results from teachers and students in this digital age. To accomplish these goals, appropriate fulfillments of digital content, funding, infrastructure, leadership, and professional development are needed. This report states that each major component is significantly related to each other and recommends that interactive instructional systems/applications need to have effective functionality when importing/exporting, formatting, and combining of electronic textual and visual information to make sure that students in K-12 classrooms are actively engaged. In regard to this concern, teachers' perception towards such interactive tools, like IWB, may play an important role in determining product purchase and training, since matters of leadership (e.g. lead teachers in technology use) and professional development (e.g. IT training) are affected by each other. This implies that positive and negative perceptions by teachers may influence the determination of decision makers on educational technology purchasing issues $[13,24]$. Since this study found that pre-service and in-service teachers saw potential benefits when utilizing IWB, (a) student-engaged learning with such instructional tools may occur, as the learning facilitates interaction among instructors and students: "Other uses of the IWB become possible and teaching with the new tool develops interactivity" [17, p. 77]; "SMART IWB offered ... such as how to integrate them into classroom instruction and how to develop lessons that take advantage of the interactivity" $[13$, p. 10] and (b) their positive perception, if occurred, may pursue effective instructional outcomes, although the teachers do not have actual experience with IWB implementation, as considered "if teachers do not value the benefits from technology, they may be reluctant to use it for instructional purposes" [25, p. $1651]$.

However, in spite of the positive perceptions found in this study, it also found several concerns with future IWB implementation such as training/help support and funding. Teachers in the previous studies expressed that (a) appropriate training sessions are critically needed and (b) constant help of IT department and lead teachers is notably suggested, because teachers cannot effectively utilize new products without competency in technical operation; they consider such supports more valuable than reviewing text-based manuals [26]. Similar to the previous teachers' standpoints, other teachers in this study also stressed relevant training opportunity and timely technical support for installation and maintenance. Among the various training 
methods, the previous study indicates that electronic training videos may help faculty members learn a new instructional technology application, because it can have full explanatory narrations by trainers, static/moving visual presentations, and viewing control features without limitation of space and time [27]. Currently, Indiana University System and other institutions have institutional subscription memberships with Lynda.com, which provides users with hundreds of web-based training videos, and it has received positive outcomes. For example, Indiana University System had a 2 year pilot study program with Lynda.com and extended its annual subscription to three more years, due to positive outcomes by users in the System [28]. This implies that, if $\mathrm{K}-12$ teachers have access to web-based training videos by various companies, they would partially compensate the lack of appropriate support which demands people's involvement. Currently, many educational video service companies (e.g. Core Curriculum Content Inc.) have offered electronic educational and training videos, and, because of benefits of such services, K-12 schools/districts have subscribed institutional memberships (e.g. Warsaw Community School District, IN). However, sufficient funding has always been a key matter in K-12 environment [18].

In K-12 environment, funding has been a critical factor to determine instructional technology purchase, and the very recent survey [13] demonstrated that this funding was the core factor. The survey with more than 500 participants (K-12 teachers; principals; superintendents; IT specialists; the related) revealed major factors of technology purchase. In findings, funding was ranked top (28.4\%), whereas "trends/needs assessment, staff-buy-in/ease of use/training, technology plan/refresh cycle" $(20.1 \%, 10.3 \%$, and $9.1 \%$ respectively; p.4) ranked lower. This implies that issues of funding and perception may be key aspects to affect purchase determination, along with (a) assessment aspect in which teachers' perceptions may partially have impact on [29] and (b) easiness of use/training in which teachers' experience/readiness may relatively affect their willingness to utilize such technology [30].

"A general consensus emerging from the literature is that the effective integration of technology into classroom practice is not widespread" [31, p.415], and this kind of phenomenon may be derived from insufficiency of practice time, infrastructure, support staff, and teachers' perceptions on technology-integrated pedagogy [31]. Thus, applying discoveries from this study into further understanding with the previous studies, matters of proper acquisition and effective implementation of interactive technology tools in classrooms may still be affected by teachers' perceptions, even though they do not fully experience products.

\section{Conclusion}

Most of pre-service and in-service teachers in this study seem to indicate that IWB implementation may (a) facilitate interaction between teachers and students, (b) promote student learning engagement, and (c) enable a group activity with interactive technology. Furthermore, many of them seem to express that (a) a proper tech support and appropriate training resources are critical for the beginning users and (b) user-friendly product design is a key factor to sustain teachers' effective utilization, and (c) insufficient funding is likely to prevent teachers from acquiring this system in a timely manner. Additionally, this study suggests that the participants' current perceptions toward the use of IWB may shift to more or less positive, if granted the opportunity to operate IWB in their local schools, since perceptions are transitioned through real life experience [31]. Furthermore, considering certain facts such as (a) the locality of participant population and its limitations and (b) the learning resources of IWB in this study were exclusively electronic, further studies may discover different research findings, as this study and previous studies have found potential and tangible benefits, barriers, and concerns to improve teaching practice and student learning integrated with interactive technology tools in K-12 environments.

\section{REFERENCES}

[1] Bitter, G. \& Legacy, J., Using technology in the classroom, Allyn and Bacon, New Jersey, US, 2008.

[2] Betcher, C., The interactive whiteboard revolution: teaching with IWBs. ACER Press, Victoria, Canada, 2009.

[3] Cuban, L, High-tech schools, low-tech teaching. Education Digest, Vol. 64, No.5, 53, 1999.

[4] Friedman, T. L., The world is flat: a brief history of the twenty-first century (1st ed.), Farrar, Straus and Giroux, New York, 2007.

[5] Partnership for 21st Century Skills, American management association critical skills survey, Tucson, Arizona, US, 2010.

[6] Jenkins, H., Confronting the challenges of participatory culture: media education for the 21 st century, The MacArthur Foundation, 2006.

[7] Shaffer, D., How computer games help children learn, Palgrave Macmillan, New York, 2006.

[8] Hughes, J., The role of teacher knowledge and learning experience in forming technology-integrated pedagogy, Journal of Technology and Teacher Education, Vol.13, No.2, 277-302, 2005.

[9] O'Bannon, B. \& Puckett, K., Preparing to use technology: a practical guide to curriculum integration, Pearson, Boston, 2010 .

[10] Rogers, E. M., Diffusion of innovations (5th ed.), Free Press, New York, 2003.

[11] Armstrong, V. et al., Collaborative research methodology for investigating teaching and learning: the use of interactive whiteboard technology, Educational Review, Vol. 57, No.4, 455-469, 2005. 
[12] Tanner, H., Jones, S., \& Beauchamp, G., Interactive whole class teaching and interactive white boards, Paper presented at the meeting of the Mathematics Education Research Group of Australasia, Melbourne, Australia, 2005.

[13] Technology Horizon in Education, Leveraging interactive whiteboards as a core classroom technology, T.H.E. Journal, $1-12,2011$

[14] Groenke, S., Missed opportunities, misunderstandings, and misgivings: a case study analysis of three beginning English teachers' attempts at authentic discussion with adolescents in a synchronous CMC environment, Journal of Technology and Teacher Education, Vol.18, No.3, 387-414, 2010.

[15] Harris, J., Mishra, P., \& Koehler, M., Teachers' technological pedagogical content knowledge and learning activity types: curriculum-based technology integration reframed, Journal of Research on Technology in Education, Vol. 41, No.4, 393-416, 2009.

[16] Pegler, K., Kollewyn, J., \& Crichton, S., Generational attitudes and teacher ICT use, Journal of Technology and Teacher Education, Vol.18, No.3, 443-458, 2010.

[17] Morais, B., Learning to use interactive white boards in the science department: a case study (Unpublished master thesis), King's College, London, 2005.

[18] Judge, S., Pucket, K., \& Bell, S., Closing the digital divide: update from the early childhood longitudinal study, The Journal of Educational Research, Vol.100, No.1, 52-60, 2006.

[19] Norris, P., The worldwide digital divide: information poverty, the Internet and development. London School of Economics and Political Science: Political Studies Association of the UK, $1-10,2000$.

[20] Brizuela, B.M., Stewart, J.P., Carrillio, R.G., \& Berger, J.G. (Eds.), Acts of inquiry in qualitative research, Harvard Educational Review, Cambridge, Massachusetts, 2000.

[21] Glesne, C., Becoming qualitative researchers (2nd ed.),
Longman, New York, 1999.

[22] Agresti, A. \& Finlay, B., Statistical methods for the social sciences (3rd ed.), Prentice Hall, New Jersey, US, 1997.

[23] Valadez, J. \& Duran, R., Redefining the digital divide: beyond access to computers and the Internet, The High School Journal, 31-44, 2007.

[24] Intel Corporation., Blueprint solutions: digital content in the k-12 classroom (Monograph). Intel Corporation, 2010.

[25] Hohlfeld, T.N., Ritzhaupt, A.D., Barron, A.E., \& Kemker, K., Examining the digital divide in k-12 public schools: four-year trends for supporting ICT literacy in Florida, Computers \& Education, Vol.51, 1648-1663, 2008.

[26] Teclehaimanot, B., Mentzer, G., \& Hickman, T., A mixed methods comparison of teacher education faculty perceptions of the integration of technology into their courses and student feedback on technology proficiency, Journal of Technology and Teacher Education, Vol. 19, No.1, 5-21, 2011.

[27] Heinich, R., Molenda, M., Russell, J.D., and Smaldino, S.E., Instructional media and technologies for learning (7th ed.), Merill/Prentice Hall, New Jersey, US, 2001.

[28] Online Available: http://ittraining.iu.edu/lynda/default.aspx, University Information Technology and Services, 2011.

[29] Pederson, S. \& Liu, M., Teachers' beliefs about issues in the implementation of a student centered learning environment, Educational Technology Research \& Development, Vol. 51, No.2, 57-76, 2003.

[30] Sahin, Y. \& Oxford, R.L., Teacher education students' perceptions of the value of handouts accompanying teacher educators' computer-generated slide presentations, Journal of Technology and Teacher Education, Vol.18, No.3, 509-535, 2010 .

[31] Sternberg, R.J. \& Wagner, R.J. (Eds.), Readings in cognitive psychology, Harcourt Brace College Publishers, Forth Worth, Texas, 1999. 